УДК: 355.237.3:615.825

Вадим Шемчук, кандидат педагогічних наук, Національний університет оборони України імені Івана Черняховського ORCID ID 0000-0001-8873-0443

Назарій Вербин, кандидат педагогічних наук, Національний університет оборони України імені Івана Черняховського ORCID ID 0000-0002-1977-3471

Оксана Шемчук, кандидат психологічних наук, Українська військово-медична академія ORCID ID 0000-0002-0641-0313

Андрій Матвсєв, Національний університет оборони України імені Івана Черняховського ORCID ID 0000-0003-3509-3289

Сергій Гайдаров, Національний університет оборони України імені Івана Черняховського ORCID ID 0000-0003-4286-8679

DOI: $10.33099 / 2617-1775 / 2021-02 / 283-304$

\title{
МЕТОДИКА ФІЗИЧНОЇ ТЕРАПІЇ МАЙБУТНІХ ОФІЦЕРІВ ІЗ ВИКОРИСТАННЯМ ЗАСОБІВ КІНЕЗІОЛОГІЧНОГО ТЕЙПУВАННЯ
}

Розглянуто актуальну проблему впровадження в систему професійної освіти (освітній процес) майбутніх офіцерів інституцій сектора безпеки і оборони Украйни (СБОУ) сучасних методик фізичної терапії. Враховуючи результати аналізу науково-методичної, довідкової та спеціальної літератури (моніторингу Інтернет-ресурсів) у обраному напрямі дослідження, членами науково-дослідної групи розроблено та апробовано методику фізичної терапії майбутніх офіцерів Збройних Сил Украӥни, Національної гвардії України та Національної полічії України із використанням засобів кінезіологічного тейпування в системі їхньӧ̈ фізичної підготовки. Нами встановлено, щуо результати, отримані наприкіниі педагогічного експерименту у досліджуваних групах, зросли відносно вихідних даних, $і$ изі відмінності переважно є достовірні $(E \Gamma, p \leq 0,05)$. Аналізуючи результати емпіричного дослідження, членами науково-дослідної групи встановлено, щьо розроблена нами методика фізичної терапії майбутніх офіцерів зазначених вище інституцій СБОУ із використанням засобів кінезіологічного тейпування в системі їхньої фізичної підготовки $є$ достатньо збалансованою та ефективною, про щчо свідчать показники виконання навчально-бойових (службово-бойових) завдань (заліків та екзаменів з основних навчальних дисииплін, зокрема фізичної та спеціальної фізичної підготовки) передбачених освітніми програмами підготовки майбутніх офіцерів Збройних Сил Украӥни, Національної гвардії Украӥни та Начіональної полічії України. Напрями подальших досліджень у обраному напрямі наукової розвідки передбачають удосконалення системи спеціальної фізичної підготовки майбутніх офічерів інституиій СБОУ із урахуванням їхньої майбутньої військово-облікової спеціальності.

Ключові слова: готовність; ерготерапія; курсанти; методика; професійна освіта; професійні компетентності; фізична підготовка; фізична терапія. 
Постановка проблеми. Політична криза у світі, гібридна війна на сході України, загострення криміногенної ситуації в країні та інші суспільні негаразди потребують високої професійної підготовленості від представників інституцій сектору безпеки і оборони України, зокрема - майбутніх офіцерів.

На сьогодні підготовка офіцерських кадрів для потреб інституцій сектору безпеки i оборони України (СБОУ) здійснюється у вищих військових навчальних закладах, або у закладах вищої освіти зі специфічними умовами навчання. Варто також зауважити, що на базі вище зазначених спеціалізованих закладів вищої освіти здійснюється військова підготовка за програмою підготовки офіцерів запасу. Важливим $є$ те, що організація системи підготовки офіцерських кадрів для потреб інституцій СБОУ здійснюється із урахуванням наявного бойового досвіду, а також урахуванням стандартів НАТО тощо.

Формування професійної компетентності у майбутніх офіцерів (курсантів вищих військових навчальних закладів, військових навчальних підрозділів закладів вищої освіти зі специфічними умовами навчання, які готують кадри для інституцій СБОУ) здійснюється в освітньому процесі, який передбачає опанування ними низкою навчальних дисциплін, серед яких основними є: обрана військово-облікова спеціальність, вогнева підготовка, фізична підготовка та тактична підготовка. Враховуючи вище викладене, прослідковується важливість саме фізичної та спеціальної фізичної підготовленості майбутніх офіцерів, адже без достатнього рівня сформованості необхідних військово-прикладних навичок неможливо забезпечити виконання завдань за призначенням у різних умовах службово-бойової (оперативної) діяльності (СБОД), що підкреслює актуальність обраного напряму наукової розвідки.

Необхідно також підкреслити, що під час освітнього процесу курсантів вищих військових навчальних закладів (ВВНЗ), закладів вищої освіти зі специфічними умовами навчання (ЗВОСУН), які готують кадри для інституцій СБОУ можливим є отримання травм різної складності, зокрема травм колінного суглобу, що може призвести до тривалого періоду лікування, а також відновлення. Це, у свою чергу, негативно впливає на якість та ефективність формування професійної компетентності курсантів ВВНЗ, ЗВОСУН відповідної інституції СБОУ і у майбутньому може призвести до низького рівня виконання ними та їх підлеглими службово-бойових завдань.

Доцільно також відмітити, що враховуючи характер, а також динаміку бойових дій на сході нашої держави, можливим є отримання травм (поранень) військовослужбовцями рядового та сержантського складу Збройних Сил України (ЗСУ), Національної гвардії України (НГУ), Служби безпеки України (СБУ), Національної поліції України (НПУ) тощо, які у майбутньому $\epsilon$ потенційними кандидатами на навчання у ВВНЗ та ЗВОСУН.

Враховуючи вище викладене, на сьогодні актуальним та своєчасним $є$ розроблення прикладних методик, програм, тощо фізичної терапії (ерготерапії) представників різних інституцій СБОУ, зокрема курсантів ВВНЗ та ЗВОСУН, які передбачають використанням засобів кінезіологічного тейпування в системі їхньої фізичної (спеціальної фізичної) підготовки. 
Дослідження виконано відповідно до планів науково-дослідної роботи i дослідно-конструкторських робіт: науково-дослідного відділу розвитку фізичного виховання, спеціальної фізичної підготовки і спорту навчальнодослідного центру проблем фізичного виховання, спеціальної фізичної підготовки і спорту навчально-наукового інституту фізичної культури та спортивно-оздоровчих технологій Національного університету оборони України імені Івана Черняховського та профільних кафедр ВВНЗ, ЗВОСУН, які готують кадри для інституцій СБОУ відповідно до договорів про міжкафедральну співпрацю (сумісний ініціативний науковий проєкт «Фізична терапія», 2020-2021 р.p.).

Аналіз останніх досліджень і публікацій у напрямі конструювання педагогічних моделей, розроблення прикладних методики (педагогічних технологій, умов) тощо, які забезпечують формування професійної компетентності у майбутніх офіцерів СБОУ необхідних для виконання ними завдань за призначенням у різних умовах СБОД, дозволив членам науководослідної групи (В. Шемчук, Н. Вербин, О. Шемчук, С. Гайдаров, О. Хацаюк, А. Матвєєв - провідні учені та практики у обраному напрямі наукової розвідки) визначити низку наукових праць, а саме: В. Шемчука, Н. Вербина, О. Нестерова, М. Василенка, Є. Малахова [1], О. Моргунова, О. Хацаюка, I. Ковальова, О. Соколова, Є. Лозового [2], В. Шемчука, О. Хацаюка, В. Соколовського, А. Ковтуненка, О. Корнієнка, Ю. Муштатова [3], О. Хацаюка, М. Медвідя [4] та інших фахівців (О. Маркова, П. Рибалки, Ю. Самсонова, А. Турчинова, В. Ягупова).

Цікавими за своїм змістом, сутнісними характеристиками, а також науковою новизною є роботи: О. Моргунова, О. Ярещенка, О. Хацаюка [5], С. Малолєпшего, М. Калюжного, О. Хацаюка [6], Д. Оленєва, О. Петрачкова, Н. Вербина, В. Шемчука, А. Тяжиної [7], О. Хацаюка, Р. Любчича, В. Оленченка [8] та інших учених і практиків (М. Боровика, О. Соколова, Ю. Фіногенова, Ю. Чернявського, А. Чуха) - у яких окреслені основні напрями формування готовності представників інституцій СБОУ до виконання завдань за призначенням у різних умовах СБОД.

У наукових працях учених: Ю. Бриндікова [9], О. Купріненка [10], I. Ковальова, К. Бутенка [11], Г. Горпинича, В. Шемчука, Г. Коника, О. Суровова, Д. Аксьонова [12] та інших фахівців (Б. Кіндзера, Л. Русин, А. Тіткової, В. Турбана, I. Назаренка) - розкриваються актуальні питання організації системи фізичної терапії, ерготерапії представників інституцій СБОУ.

Варто також відмітити наукові праці досвідчених учених і практиків: K. Kenzo [13], Г. Гончар, Т. Булгакової, С. Лазоренка та ін. [14], Л. Русин [15], Б. Кіндзера, Н. Бабич, Р. Сіренко, І. Рибчича, І. Ільницького, Н. Петренко [16], V. Vynohradov, H. Lopatenko, S. Trachuk, V. Semenenko, M. Kudria, V. Shemchuk, A. Napadij [17] та інших фахівців (Є. Ачкасова, М. Касаткіна, Ф. Суботіна, В. Тучкова, Д. Хаміла) - у яких розкриваються особливості використання засобів кінезіологічного тейпування в системі фізичної терапії (ерготерапії) представників різних груп населення.

Не дивлячись на значну кількість робіт з обраного нами напряму наукової 
розвідки, питанням розроблення, а також апробації прикладних методик фізичної терапії (ерготерапії) здобувачів вищої освіти (майбутніх офіцерів) ВВНЗ, ЗВОСУН, які готують кадри для інституцій СБОУ в системі професійної освіти із акцентованим використанням засобів кінезіологічного тейпування присвячено недостатньо досліджень, що потребує подальших наукових розвідок.

Мета дослідження - розроблення та апробація методики фізичної терапії майбутніх офіцерів ЗСУ, НГУ, НПУ із використанням засобів кінезіологічного тейпування в системі їхньої фізичної підготовки.

Для досягнення мети дослідження планувалося вирішити наступні завдання:

- визначити ефективні педагогічні моделі (методики), педагогічні технології та умови тощо, які забезпечують формування професійної компетентності у майбутніх офіцерів СБОУ необхідних для виконання ними завдань за призначенням;

- проаналізувати актуальні науково-методичні, довідкові та спеціальні джерела у напрямі формування готовності військовослужбовців, правоохоронців СБОУ до виконання завдань за призначенням у різних умовах СБОД;

- здійснити аналіз спеціальної науково-методичної літератури у напрямі організації системи фізичної терапії, ерготерапії представників інституцій СБОУ;

- провести моніторинг Інтернет-джерел, а також аналіз довідкової та спеціальної науково-методичної літератури у напрямі використання засобів кінезіологічного тейпування в системі фізичної терапії (ерготерапії) представників різних груп населення.

Методи дослідження (на емпіричному i теоретичному рівнях): абстрагування, аналіз і синтез, індукція і дедукція, експертне оцінювання, моделювання, математично-статистичні (шкалювання) тощо. Крім цього, використано власний досвід організації системи фізичної та спеціальної фізичної підготовки майбутніх офіцерів інституцій СБОУ, а також досвід кінезіологічного тейпування (ерготерапії, фізичної терапії) представників різних груп населення.

Виклад основного матеріалу. Дослідження організовано упродовж трьох етапів (березень - листопад 2021 р.). Під час відпрацювання завдань передбачених першим етапом дослідження (березень - червень 2021p.), членами науково-дослідної групи (НДГ) проведено аналіз науково-методичної літератури (моніторинг Інтернет-ресурсів) у обраному напрямі наукової розвідки.

Враховуючи результати аналізу спеціальної науково-методичної та довідкової літератури [13-17], членами НДГ встановлено той факт, що сучасна техніка аплікації спеціальної адгезивної стрічки (кінезіологічного тейпування) грунтується на припущені, що периферичний рецептор на шкірі людини відноситься до іiі нервової системи, а структура клітини може впливати на відповідний сегмент спинного мозку, таким чином формується позитивний 
вплив (терапевтичний ефект) на організм індивіда. Необхідно також відмітити, що на сьогодні відомі наступні види кінезіологічного тейпування: лімфатична корекція «тунелювання»; зв'язкова-сухожильна корекція «тиск»; фасціальна корекція «утримання»; механічна корекція; послаблююча корекція «ліфтинг»; функціональна корекція «пружинування» [15, С. 3].

Таким чином, кінезіологічний тейп, який закріплений на тілі людини здійснює стимуляцію рецепторів шкіри, що позитивно впливає на його нервову систему. Варто також зауважити, що кінезіологічне тейпування із використанням різних методик $\epsilon$ додатковим засобом оперативного та контрольованого формування суглобо-м'язових відчуттів, а також покращення управління спеціалізованих рухів індивіда. Крім цього, кінезіологічне тейпування із використанням сучасних методик в системі фізичної терапії (ерготерапії) людини дозволяє відчути та уявити м'язи у вигляді органу пізнання, а також джерела додаткової інформації.

Враховуючи вище викладене, доцільно констатувати, що також можливим $\epsilon-$ прискорення термінів відновлення після травм різного роду та повернення до активних і систематичних занять обраним видом спорту, практичних занять 3 вогневої, тактичної та фізичної підготовки тощо, в системі багаторічної підготовки (професійної освіти) курсантів ВВНЗ та ЗВОСУН.

Упродовж другого етапу дослідження (червень - серпень 2021 р.) членами НДГ було проаналізовано низку спеціалізованих науково-методичних джерел $[1,3,4,7,9]$, у яких висвітлені актуальні питання формування професійної компетентності майбутніх офіцерів різних інституцій СБОУ в системі їхньої багаторічної підготовки. Нами встановлено, що існуюча система підготовки офіцерських кадрів для потреб інституцій СБОУ не в повній мірі використовує засоби ерготерапії та фізичної терапії, які передбачають використання сучасних технік кінезіологічного тейпування, що негативно впливає на терміни та ефективність відновлення військовослужбовців (правоохоронців) різних категорій, представників різних інституцій СБОУ після травм, цим самим знижується ефективність їхньої професійної підготовки (сповільнюється процес формування професійної компетентності).

Крім цього, відповідно до статистичних звітів фахівців медичної служби ВВНЗ, та ЗВОСУН інституцій СБОУ встановлено, що основні навчальні дисципліни (предмети бойової підготовки), які забезпечують формування ключових професійної компетентності у майбутніх офіцерів (військовослужбовців різних категорій та вікових груп) на сьогодні $є$ досить ризико-небезпечними у напрямі отримання ними травм (на рис. 1 надано статистику травмування курсантів ВВНЗ, ЗВОСУН в освітньому процесі). 


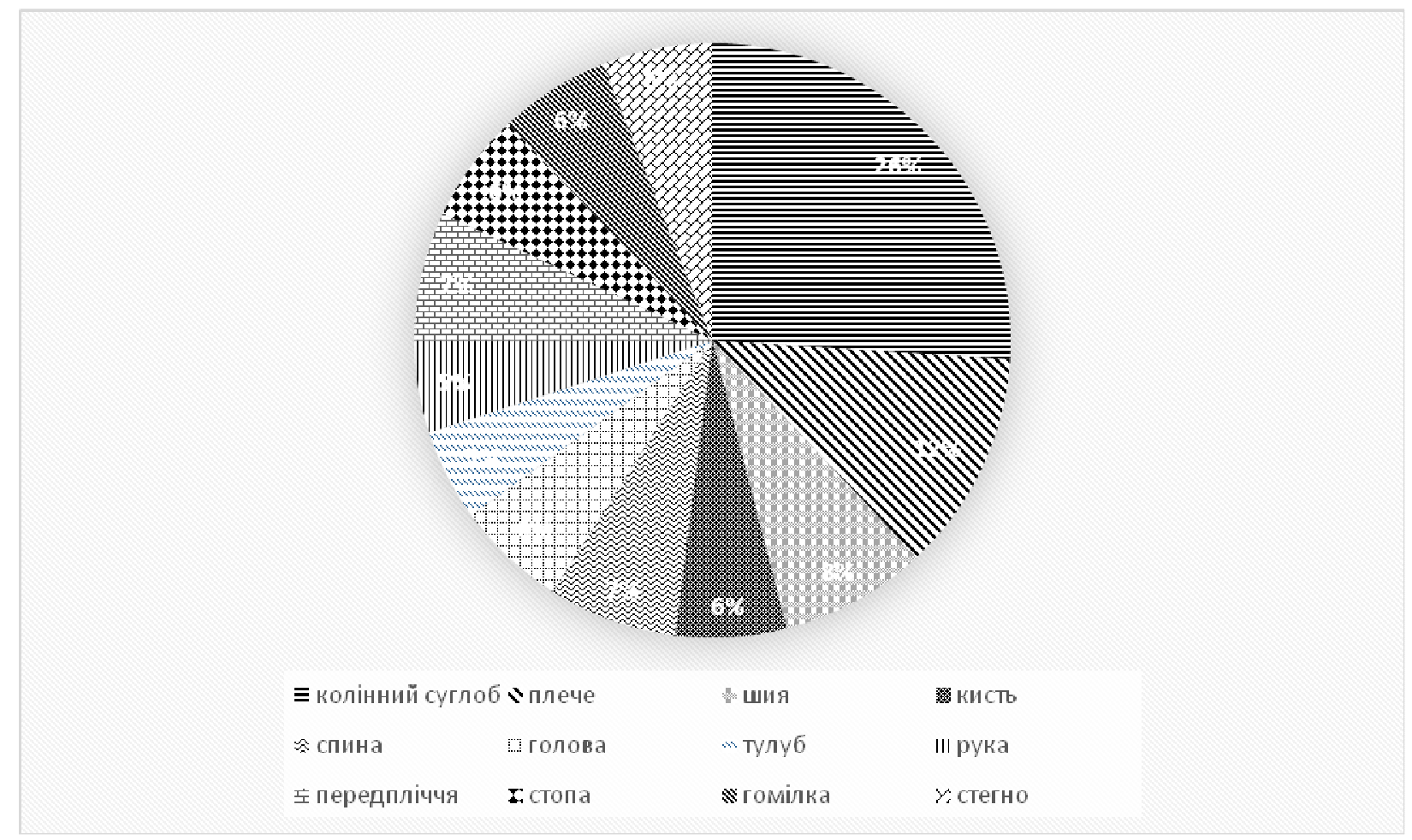

Рис. 1. Статистика отримання травм майбутніми офіцерами інституцій СБОУ в системі їхньої багаторічної підготовки (у \%, використана статистика фахівців медичної служби ВВНЗ ЗСУ, НГУ, НПУ, а також ЗВОСУН НПУ за 2019-2021 p.p.)

Аналізуючи характер травмування та статистику надану на рис. 1, членами НДГ встановлено, що найбільше випадків травмування припадає на колінний суглоб, що потребує відповідних превентивних заходів, а також розроблення ефективних методик фізичної терапії (ерготерапії) майбутніх офіцерів в системі їхньої фізичної підготовки, яка за своїм призначенням (основними завданнями) забезпечує готовність представників інституцій СБОУ до виконання завдань за призначенням, а також сприяє ефективному відновленню після травм, хвороб (поранень) тощо. Варто також зауважити, що основними травмами колінного суглобу є: тендиніт зв'язки надколінника, синдром рухового надколінника, латерально зміщенний надколінник, підвивих надколінника, хондромаляція надколінника, складка колінного суглобу, синдром Огсуда-Шлягера і ЛарсенаЙохансона, ушкодження передньої хрестоподібної зв'язки, ушкодження медіальної колатеральної зв'язки, перерозгинання колінного суглобу, ушкодження менісків колінного суглобу, остеоартрит колінного суглобу, бурсити колінного суглобу тощо.

Особливості програми фізичної терапії:

1) тривалість програми фізичної терапії складає 3 місяці (4 заняття на тиждень);

2) під час кінезіологічного тейпування обов'язково використовувати сертифіковані та безпечні адгезивні стрічки;

3) застосування методики фізичної терапії із використанням технік кінезіологічного тейпування при травмах колінного суглобу на етапі фізичної 
терапії організовувати під керівництвом фахівців фізичного виховання (фізичної підготовки) із медичним супроводом провідних лікарів;

4) підготовчу частину організовувати відповідно до самопочуття досліджуваних курсантів (враховувати особливості та характер травм чи хвороби);

5) контрольне тестування сформованості фізичних якостей (військовоприкладних навичок) організувати за окремим планом;

6) дозування навантаження відповідно до самопочуття та індивідуальнотипологічних особливостей досліджуваних курсантів.

Алгоритм нанесення адгезивної кінезіологічної стрічки:

1) визначити ділянку, де відчувається м'язова утома чи біль;

2) перед аплікацією очистити (обезжирити) шкіру використовуючи спиртові антисептики;

3) відміряти смужку(ки) адгезивної стрічки відповідної довжини та ширини;

4) скласти адгезивну стрічку навпіл та закруглити їі кінці за допомогою ножиць;

5) надірвати паперову захисну стрічку на відстані 3-4 см від кінця адгезивної стрічки для створення основи ії аплікації («якоря»);

6) здійснити достатній натяг поверхневих тканин на яку буде здійснено накладення тейпу, прикріпити «якір» у місці з’єднання (прикріплення м'язів) та належним чином розгладити «якір» руками;

7) повільно відклеїти решту паперової підкладки, залишивши на протилежному кінці місце для другого «якора» (у разі необхідності нанесення аплікації Ү-подібної смужки необхідно спершу відклеїти паперову основу одного із «хвостиків», після чого завершити аплікацію знявши паперову основу з іншого «хвостика», другий «якір» наклеїти без натягу);

8) розгладження адгезивної стрічки здійснювати завжди від середини до ії країв;

9) адгезивну стрічку накладати за 30-40 хв до фізичних навантажень, після прийому душу необхідно сухим полотенцем їі підсушити.

Відповідно до вище викладеного, нами обгрунтовано доцільність впровадження в систему фізичної підготовки курсантів ВВНЗ, та ЗВОСУН інституцій СБОУ уніфікованої методики фізичної терапії, яка передбачає використання засобів кінезіологічного тейпування (табл. 1).

Таблиия 1

Методика фізичної терапії курсантів ВВНЗ (ЗВО) зі специфічними умовами навчання інституцій сектору безпеки і оборони із використанням засобів кінезіологічного тейпування колінного суглобу в системі фізичної підготовки

\begin{tabular}{|c|c|c|c|}
\hline \multirow{2}{*}{$№$ 3/II } & $\begin{array}{c}\text { № заняття та зміст } \\
\text { тренувальних } \\
\text { завдань }\end{array}$ & $\begin{array}{c}\text { Тривалість } \\
\text { заняття (хв) }\end{array}$ & $\begin{array}{c}\text { Організаційно-методичні } \\
\text { вказівки }\end{array}$ \\
\hline 1 & 2 & 3 & 4 \\
\hline
\end{tabular}


продовження таблиці 1

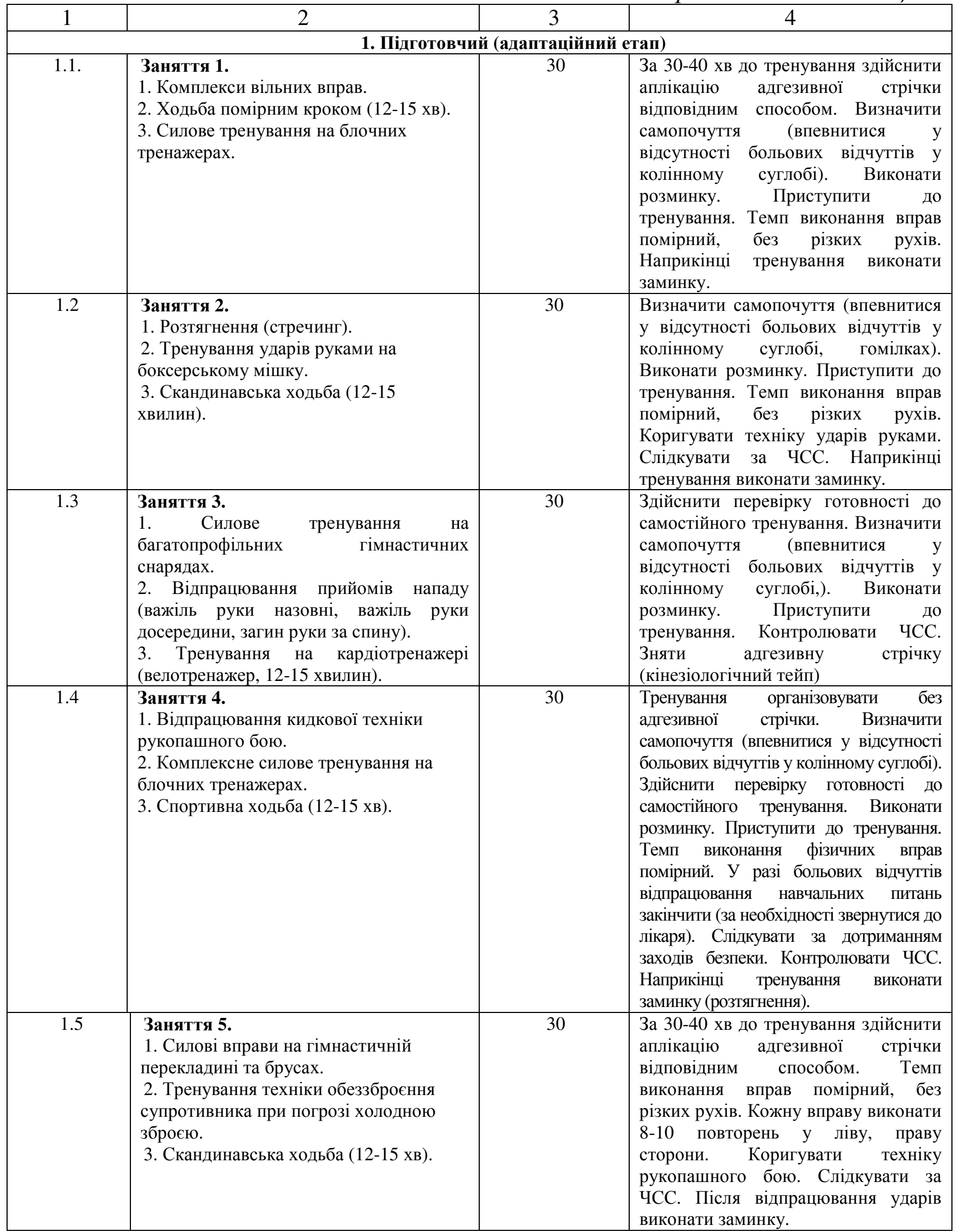


продовження табличі 1

\begin{tabular}{|c|c|c|c|}
\hline 1 & 2 & 3 & 4 \\
\hline 1.6 & $\begin{array}{l}\text { 3аняття 6. } \\
\text { 1. Комплекси вільних вправ. Комплекси } \\
\text { рукопашного бою (дихальні ката). } \\
\text { 2. Вправи для м’язів ніг на силових } \\
\text { (блочних) тренажерах. } \\
\text { 3. Тренування на кардіотренажері } \\
\text { (гребний концепт, 12-15 хв). }\end{array}$ & 30 & $\begin{array}{lrr}\text { Здійснити } & \text { перевірку готовності до } \\
\text { самостійного } & \text { тренування. } & \text { Визначити } \\
\text { самопочугтя } & \text { (впевнитися у } & \text { відсугності } \\
\text { больових в відчугтів у колінному суглобі). } \\
\text { Виконати розминку. Темп виконання вправ } \\
\text { помірний, без різких рухів. Кожну вправу } \\
\text { виконати 8-10 повторень уліву, праву сторони. } \\
\text { Слідкувати за ЧСС. Наприкінці тренування } \\
\text { виконатизаминку. }\end{array}$ \\
\hline $\begin{array}{l}1.7 \\
\end{array}$ & $\begin{array}{l}\text { Заняття } 7 . \\
\text { 1. Розтягнення (стречинг). } \\
\text { 2. Тренування техніки обеззброєння } \\
\text { супротивника при погрозі пістолетом. } \\
\text { 3. Помірний біг (8-10 хв). }\end{array}$ & 30 & $\begin{array}{l}\text { Визначити самопочугтя (впевнитися у } \\
\text { відсуності больових відчугтів у колінному } \\
\text { суглобі). Здійснити перевірку готовності до } \\
\text { самостійного тренування. Виконати } \\
\text { розминку. Темп виконання вправ помірний, } \\
\text { без різких рухів. Коригувати техніку } \\
\text { рукопашного бою та бігу. Слідкувати за ЧСС } \\
\text { та диханням. Наприкінці тренування } \\
\text { виконати заминку. }\end{array}$ \\
\hline 1.8 & $\begin{array}{l}\text { Заняття 8. } \\
\text { 1. Вправи для м'язів ніг на силових } \\
\text { (блочних) тренажерах. } \\
\text { 2. Тренування техніки звільнення від } \\
\text { захоплень та обхватів. } \\
\text { 3. Спортивна ходьба (12-15 хв). }\end{array}$ & 30 & $\begin{array}{l}\text { Тренування проводити без адгезивної } \\
\text { стрічки. Визначити самопочуття } \\
\text { (впевнитися у відсутності больових } \\
\text { відчугтів у колінному суглобі). Здійснити } \\
\text { перевірку готовності до самостійного } \\
\text { тренування. Виконати розминку. Темп } \\
\text { виконання вправ помірний, без різких } \\
\text { рухів. Коригувати техніку рукопашного } \\
\text { бою. Слідкувати за ЧСС. Наприкінці } \\
\text { тренування виконати заминку. }\end{array}$ \\
\hline 1.9 & $\begin{array}{l}\text { Заняття 9. } \\
\text { 1. Комплекси рукопашного бою } \\
\text { (дихальні ката). } \\
\text { 2. Комплексне силове тренування } \\
\text { круговим способом. } \\
\text { 3. Скандинавська ходьба (12-15 хв). }\end{array}$ & 30 & $\begin{array}{l}\text { За } 30-40 \text { хв до тренування здійснити } \\
\text { aплікацію адгезивної стрічки відповідним } \\
\text { способом. Здійснити перевірку готовності } \\
\text { до самостійного тренування. Визначити } \\
\text { самопочугтя (впевнитися у відсутності } \\
\text { больових відчугтів у колінному суглобі). } \\
\text { Виконати розминку. Темп виконання } \\
\text { вправ помірний, без різких рухів. } \\
\text { Слідкувати за технікою ходьби та вірним } \\
\text { диханням. Наприкінці тренування } \\
\text { виконати заминку. }\end{array}$ \\
\hline 1.10 & $\begin{array}{l}\text { Заняття 10. } \\
\text { 1. Вправи на брусах та гімнастичній } \\
\text { перекладині. } \\
\text { 2. Тренування прийомів бою зі зброєю. } \\
\text { 3. Тренування на кардіотренажері } \\
\text { (велотренажер, 12-15 хв). }\end{array}$ & 30 & $\begin{array}{l}\text { Визначити самопочугтя (впевнитися у } \\
\text { відсупності больових відчуттів у } \\
\text { колінному суглобі та гомілках). Здійснити } \\
\text { перевірку готовності до самостійного } \\
\text { тренування. Виконати розминку. Темп } \\
\text { виконання вправ помірний, без різких } \\
\text { pухів. Коригувати техніку прийомів бою } \\
\text { зі зброєю. Наприкінці тренування } \\
\text { виконати заминку. }\end{array}$ \\
\hline 1.11 & $\begin{array}{l}\text { Заняття } 11 . \\
\text { 1. Розтягнення (стречинг). } \\
\text { 2. Відпрацювання ударів руками та } \\
\text { ногами на важких боксерських мішках. } \\
\text { 3. Помірний біг (10-12 хв). }\end{array}$ & 30 & $\begin{array}{l}\text { Здійснити перевірку готовності до } \\
\text { самостійного тренування. Виз-начити } \\
\text { самопочугтя (впевнитися у відсутності } \\
\text { больових відчугтів у колінному суглобі } \\
\text { та ногах). Виконати розминку. Темп } \\
\text { виконання вправ помірний, без різких } \\
\text { рухів. Коригувати техніку ударів руками } \\
\text { та ногами. Під час бігу слідкувати за } \\
\text { ЧСС та диханням. Наприкінці } \\
\text { тренування виконати заминку. Зняти } \\
\text { адгезивну стрічку. }\end{array}$ \\
\hline
\end{tabular}


продовження табличі 1

\begin{tabular}{|c|c|c|c|}
\hline 1 & 2 & 3 & 4 \\
\hline 1.12 & $\begin{array}{l}\text { Заняття 12. } \\
\text { 1. Скандинавська ходьба (12-15 хвилин). } \\
\text { 2. Дихальні ката (комплекси вільних } \\
\text { вправ). } \\
\text { 3. Тренування на кардіотренажері } \\
\text { (велотренажер, 12-15 хв). }\end{array}$ & 30 & $\begin{array}{l}\text { Тренування проводити без адгезивної } \\
\text { стрічки } \\
\text { Визначити самозіологічного тейпу). } \\
\text { відсутності больовя (впевнитися у } \\
\text { колінному суглобі, ногах). Здійснити } \\
\text { перевірку готовності до самостійного } \\
\text { тренування. Виконати розмику. Темп } \\
\text { виконання вправ помірний, без різких } \\
\text { рухів. Наприкінці тренування виконати } \\
\text { заминку. }\end{array}$ \\
\hline \multicolumn{2}{|c|}{ Всього за підготовчий (адаптаційний блок) } & 360 & $-\ldots$ \\
\hline \multicolumn{4}{|c|}{ 2. Формувальний етап } \\
\hline 1.13 & $\begin{array}{l}\text { Заняття } 13 . \\
\text { 1. Силові вправи на багато прольотних } \\
\text { снарядах. } \\
\text { 2. Відпрацювання кидкової техніки } \\
\text { рукопашного бою. } \\
\text { 3. Спортивна ходьба (15-20 хв). }\end{array}$ & 45 & $\begin{array}{l}\text { За } 30-40 \text { хв до тренування здійснити } \\
\text { аплікацію адгезивної стрічки відповідним } \\
\text { способом. Здійснити перевірку готовності } \\
\text { до самостійного тренування. Визначити } \\
\text { самопочуття (впевнитися у відсутності } \\
\text { больових відчуттів у колінному суглобі, } \\
\text { ногах). Виконати розминку. Темп } \\
\text { виконаня вправ помірний, без різких } \\
\text { pухів. Корегувати кидкову техніку. } \\
\text { Слідкувати за технікою ходьби. } \\
\text { Наприкінці тренування виконати заминку. }\end{array}$ \\
\hline 1.14 & $\begin{array}{l}\text { Заняття } 14 . \\
\text { 1. Стречинг (розтягнення). Комплекси } \\
\text { дихальних вправ. } \\
\text { 2. Тренування техніки човникового бігу } \\
\text { 10х10м. } \\
\text { 3. Скандинавська ходьба (15-20 хв). }\end{array}$ & 45 & $\begin{array}{l}\text { Визначити самопочуття (впевнитися у } \\
\text { відсутності больових відчугтів у } \\
\text { колінному суглобі, ногах). Виконати } \\
\text { розминку. Приступити до тренування. } \\
\text { Темп виконання вправ помірний, без } \\
\text { різких рухів. Коригувати техніку } \\
\text { mовникового бігу. Слідкувати за ЧСС. } \\
\text { Наприкінці тренування виконати заминку. }\end{array}$ \\
\hline 1.15 & $\begin{array}{l}\text { Заняття } 15 . \\
\text { 1. Відпрацювання техніки обеззброєння } \\
\text { супротивника при ударах ножем. } \\
\text { 2. Силові вправи для м'язів ніг на } \\
\text { блочних тренажерах. } \\
\text { 3. Тренування на кардіотренажері } \\
\text { (гребний концепт, 15-20 хв). }\end{array}$ & 45 & $\begin{array}{l}\text { Здійснити перевірку готовності до } \\
\text { самостійного тренування. Визначити } \\
\text { самопочугтя (впевнитися у відсутності } \\
\text { больових відчуттів у колінному суглобі, } \\
\text { ногах). Виконати розминку. Приступити } \\
\text { до тренування. Контролювати ЧСС. Зняти } \\
\text { адгезивну стрічку (кінезіологічний тейп). }\end{array}$ \\
\hline 1.16 & $\begin{array}{l}\text { Заняття 16. } \\
\text { 1. Тренування техніки бігу на } 60 \text { м } 3 \\
\text { високого старту. } \\
\text { 2. Тренування прийомів рукопашного } \\
\text { бою зі зброєю. } \\
\text { 3. Тренування техніки бігу на } 1 \text { км. }\end{array}$ & 45 & $\begin{array}{l}\text { Тренування проводити без адгезивної } \\
\text { стрічки. Здійснити перевірку готовності } \\
\text { до самостійного тренування. Визначити } \\
\text { самопочуття (впевнитися у відсутності } \\
\text { больових відчуттів у колінному суглобі). } \\
\text { Виконати розминку. Темп виконання } \\
\text { вправ помірний, без різких рухів. } \\
\text { Коригувати техніку прийомів бою зі } \\
\text { зброєю. Контролювати чСС під час } \\
\text { відпрацювання бігових вправ. Заминка. }\end{array}$ \\
\hline 1.17 & $\begin{array}{l}\text { Заняття } 17 . \\
\text { 1. Тренування прийомів звільнення від } \\
\text { захоплень та обхватів. } \\
\text { 2. Тренування техніки бігу на } 100 \text { м } 3 \\
\text { високого старту. } \\
\text { 3. Спортивна ходьба (15-20 хв). }\end{array}$ & 45 & $\begin{array}{l}\text { За } 30-40 \text { хв до тренування здійснити } \\
\text { аплікацію адгезивної стрічки відповідним } \\
\text { способом. Темп виконання вправ } \\
\text { помірний, без різких рухів. Коригувати } \\
\text { техніку бігових вправ. Слідкувати за ЧСС } \\
\text { та диханням. Наприкінці тренування } \\
\text { виконати заминку. }\end{array}$ \\
\hline
\end{tabular}


продовження табличі 1

\begin{tabular}{|c|c|c|c|}
\hline 1 & 2 & 3 & 4 \\
\hline 1.18 & $\begin{array}{l}\text { Заняття } 18 . \\
\text { 1. Тренування вправ: підтягування на } \\
\text { перекладені, згинання-розгинання рук в упорі на } \\
\text { брусах. } \\
\text { 2. Відпрацювання ударно-кидкових дій } \\
\text { рукопашного бою. } \\
\text { 3. Тренування техніки бігу на 2-2,5 км. }\end{array}$ & 45 & 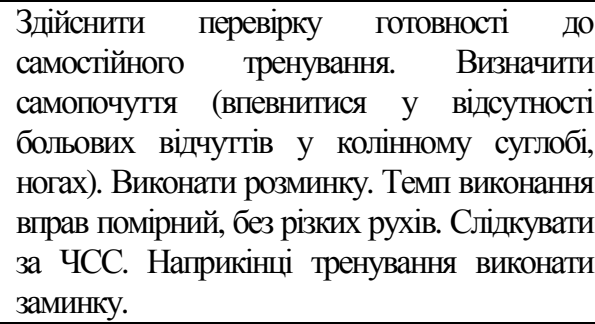 \\
\hline 1.19 & $\begin{array}{l}\text { Заняття } 19 . \\
\text { 1. Тренування техніки бігу на 60, } 100 \text { м } 3 \\
\text { високого старту. } \\
\text { 2. Силові вправи на блочних тренажерах. } \\
\text { 3. Тренування на кардіотренажері (велотренажер, } \\
\text { 12-15 хв). }\end{array}$ & 45 & $\begin{array}{l}\text { Визначити самопочугтя (впевнитися у } \\
\text { відсугності больових відчугтів у колінному } \\
\text { суглобі). Здійснити перевірку готовності до } \\
\text { самостійного тренування. Виконати } \\
\text { розминку. Темп виконання вправ помірний, } \\
\text { без різких рухів. Коригувати техніку бігових } \\
\text { вправ. Слідкувати за ЧСС та диханням під } \\
\text { час роботи на блочних тренажерах. } \\
\text { Наприкінці тренування виконати заминку. }\end{array}$ \\
\hline 1.20 & $\begin{array}{l}\text { Заняття 20. } \\
\text { 1. Розтягнення (стречинг), дихальні ката. } \\
\text { 2. Комплексне силове тренування (із } \\
\text { використанням засобів кросфіту). } \\
\text { 3. Скандинавська ходьба (15-20 хв). }\end{array}$ & 45 & $\begin{array}{l}\text { Тренування проводити без адтезивної } \\
\text { стрічки. Визначити самопочугтя (впевнитися } \\
\text { у відсугності больових відчугтів у колінному } \\
\text { суглобі, ногах). Здійснити перевірку } \\
\text { готовності до самостійного тренування. } \\
\text { Виконати розминку. Темп виконання вправ } \\
\text { помірний. Слідкувати за самопочугтям під } \\
\text { час виконання функціональних комплексів } \\
\text { кросфіт. Наприкінці тренування виконати } \\
\text { заминку. }\end{array}$ \\
\hline 1.21 & $\begin{array}{l}\text { Заняття } 21 . \\
\text { 1. тренування техніки бігу на } 100 \text { м, човникового } \\
\text { бігу 10х10 м. } \\
\text { 2. Навчально-тренувальні сугички за } \\
\text { спрощеними правилами рукопашного бою. } \\
\text { 3. Тренування на кардіотренажері (гребний } \\
\text { концегт, } 15-20 \text { хв). }\end{array}$ & 45 & 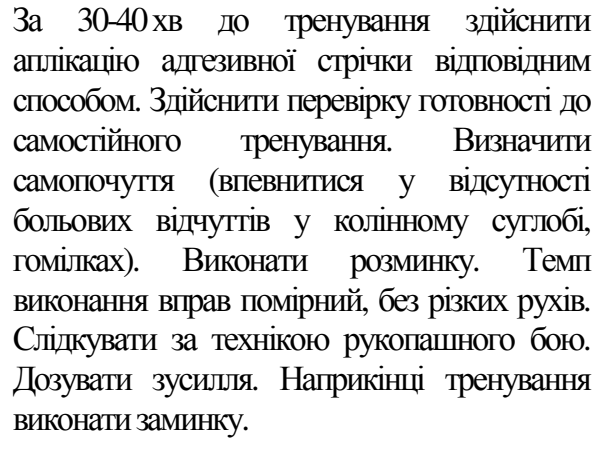 \\
\hline 1.22 & $\begin{array}{l}\text { Заняття } 22 . \\
\text { 1. Силові вправи на гімнастичних снарядах. } \\
\text { 2. Тренування техніки подолання окремих } \\
\text { перешкод (штучних). } \\
\text { 3. Тренування техніки бігу на 2,5-32 км. }\end{array}$ & 45 & $\begin{array}{l}\text { Визначити самопочугтя (впевнитися у } \\
\text { відсугності больових відчугтів у колінному } \\
\text { суглобі та гомілках). Здійснити перевірку } \\
\text { готовності до самостійного тренування. } \\
\text { Виконати розминку. Темп виконання вправ } \\
\text { помірний, без різких рухів. Коригувати } \\
\text { техніку подолання штучних та природних } \\
\text { перешкод. Наприкінці тренування виконати } \\
\text { заминку. }\end{array}$ \\
\hline 1.23 & $\begin{array}{l}\text { Заняття } 23 . \\
\text { 1. Розтягнення (стречинг). Комплекси } \\
\text { рукопашного бою. } \\
\text { 2. Тренування техніки бігу на } 400-600 \text { м. } \\
\text { 3. Скандинавська ходьба (15-20 хв). }\end{array}$ & 45 & $\begin{array}{lrr}\text { Здійснити перевірку готовності до } \\
\text { самостійного } & \text { тренування. } & \text { Визначити } \\
\text { самопочугтя } & \text { (впевнитися у } & \text { відсугності } \\
\text { больових відчугтів у колінному суглобі та } \\
\text { ногах). Виконати розминку. Темп виконання } \\
\text { вправ помірний, без різких рухів. Коригувати } \\
\text { техніку бігу. Під час бігу слідкувати за ЧСС } \\
\text { та диханням. Наприкінці тренування } \\
\text { виконати заминку. Зняти адгезивну стрічку. }\end{array}$ \\
\hline
\end{tabular}


продовження таблиці 1

\begin{tabular}{|c|c|c|c|}
\hline 1 & 2 & 3 & 4 \\
\hline 1.24 & $\begin{array}{l}\text { Заняття } 24 . \\
\text { 1. Тренування прийомів бою зі зброєю. } \\
\text { 2. Тренування вправ: підтягування на } \\
\text { перекладині, згинання-розгинання рук в } \\
\text { упорі на брусах. } \\
\text { 3. Тренування на кардіотренажері } \\
\text { (велотренажер, } 12-15 \text { хв). }\end{array}$ & 45 & $\begin{array}{l}\text { Тренування проводити без адгезивної } \\
\text { стрічки (кінезіологічного тейпу). } \\
\text { Визначити самопочуття (впевнитися у } \\
\text { відсутності больових відчуттів у } \\
\text { колінному суглобі, ногах). Здійснити } \\
\text { перевірку готовності до самостійного } \\
\text { тренування. Виконати розминку. Темп } \\
\text { виконання вправ помірний, без різких } \\
\text { рухів. Слідкувати за самопочуттям } \\
\text { (ЧСС) під час роботи на } \\
\text { кардіотренажері. } \\
\text { тренування виконати заминку. }\end{array}$ \\
\hline \multicolumn{2}{|c|}{ Всього за формувальний етап } & 540 & --- \\
\hline \multicolumn{4}{|c|}{ 3. Константувальний етап } \\
\hline 1.25 & $\begin{array}{l}\text { Заняття } 25 . \\
\text { 1. Комплексне силове тренування на } \\
\text { гімнастичних снарядах. } \\
\text { 2. Тренування техніки бігу на } 100 \text { м. } \\
\text { 3. Тренування техніки бігу на } 3 \text { км. }\end{array}$ & 90 & $\begin{array}{l}\text { За 30-40 хв до тренування здійснити } \\
\text { аплікацію } \text { адгезивної } \\
\text { відповідним стрічки } \\
\text { перевірку готовності до самостійного } \\
\text { тренування. Визначити самопочуття } \\
\text { (впевнитися у відсутності больових } \\
\text { відчуттів у колінному суглобі, ногах). } \\
\text { Виконати розминку. Темп виконання } \\
\text { вправ помірний, без різких рухів. } \\
\text { Корегувати техніку бігу. Слідкувати } \\
\text { за самопочутям та ЧСС. Наприкінці } \\
\text { тренування виконати заминку. }\end{array}$ \\
\hline 1.26 & $\begin{array}{l}\text { Заняття } 26 . \\
\text { 1. Розтягнення (стречинг), дихальні ката. } \\
\text { 2. Тренування техніки подолання } \\
\text { штучних та природних перешкод. } \\
\text { 3. Тренування на кардіотренажері } \\
\text { (гребний концепт, 15-20 хв). }\end{array}$ & 90 & 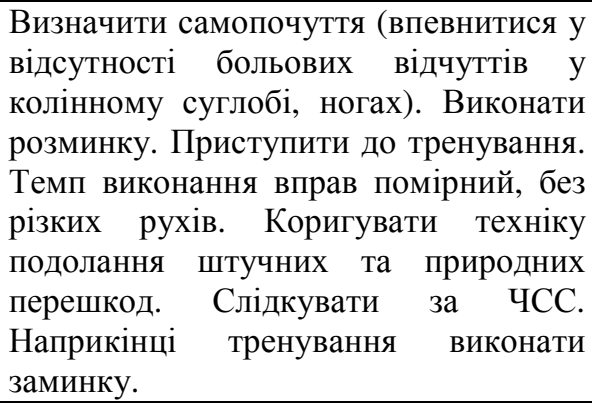 \\
\hline 1.27 & $\begin{array}{l}\text { Заняття } 27 . \\
\text { 1. Тренування прийомів обеззброєння } \\
\text { супротивника при погрозі вогнепальною } \\
\text { зброю. } \\
\text { 2. Тренування техніки човникового бігу } \\
\text { 10x10 м. } \\
\text { 3. Тренування техніки бігу на } 5 \text { км. }\end{array}$ & 90 & $\begin{array}{l}\text { Здійснити перевірку готовності до } \\
\text { самостійного тренування. Визначити } \\
\text { самопочуття } \\
\text { відсутності } \text { больових відчуттів у } \\
\text { колінному суглобі, ногах). Виконати } \\
\text { розминку. Приступити до тренування. } \\
\text { Контролювати ЧСС. Зняти адгезивну } \\
\text { стрічку (кінезіологічний тейп). }\end{array}$ \\
\hline 1.28 & $\begin{array}{l}\text { Заняття } 28 . \\
\text { 1. Тренування комплексів вільних вправ, } \\
\text { тренування комлексів рукопашного бою. } \\
\text { 2. Тренування техніки бігу на 400, 600, } \\
800 \text { м. } \\
\text { 3. Тренування на кардіотренажері } \\
\text { (велотренажер, 15-20 хв). }\end{array}$ & 90 & $\begin{array}{l}\text { Тренування проводити без адпезивної стрічки. } \\
\text { Здійснити перевірку готовності до самостійного } \\
\text { тренування. Визначити самопочугтя } \\
\text { (впевнитися у відсупності больових відчугтів у } \\
\text { колінному суглобі). Виконати розминку. Темп } \\
\text { виконання вправ помірний, без різких рухів. } \\
\text { Коригувати техніку бігу. Контролювати ЧСС } \\
\text { під час відпрацювання бігових вправ. } \\
\text { Наприкінці тренування виконатизаминку. }\end{array}$ \\
\hline 1.29 & $\begin{array}{l}\text { Заняття } 29 . \\
\text { 1. Розтягнення (стречинг), дихальні ката. } \\
\text { 2. Силові вправи на гімнастичних } \\
\text { снарядах та брусах. } \\
\text { 3. Крос по пересіченій місцевості (до 5-6 } \\
\text { км). }\end{array}$ & 90 & $\begin{array}{l}\text { За 30-40 хв до тренування здійснити } \\
\text { аплікацію адгезивної } \\
\text { відповідним способомк. Темп виконання } \\
\text { вправ помірний, без різких рухів. } \\
\text { Коригувати техніку бігу. Слідкувати за } \\
\text { ЧСС та диханням. Наприкінці } \\
\text { тренування виконати заминку. }\end{array}$ \\
\hline
\end{tabular}


продовження табличі 1

\begin{tabular}{|c|c|c|c|}
\hline 1 & 2 & 3 & 4 \\
\hline 1.30 & $\begin{array}{l}\text { Заняття 30. } \\
\text { 1. Тренування техніки човникового бігу } \\
4 x 400 \text { м. } \\
\text { 2. Відпрацювання ударно-кидкової } \\
\text { техніки службово-прикладного } \\
\text { рукопашного бою } \\
\text { 3. Тренування техніки бігу на } 1 \text { км. }\end{array}$ & 90 & 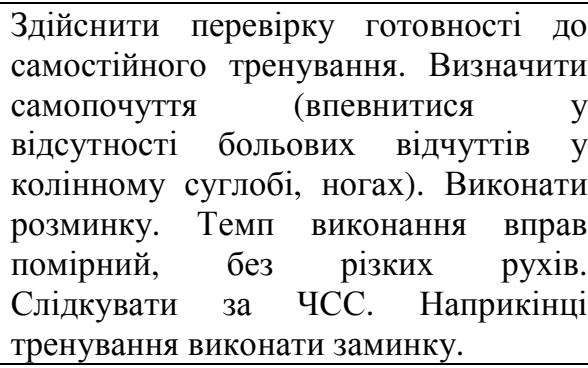 \\
\hline 1.31 & $\begin{array}{l}\text { Заняття } 31 . \\
\text { 1. Тренування техніки бігу на } 100 \text { м. } \\
\text { 2. Комплексне силове тренування на } \\
\text { блочних тренажерах. } \\
\text { 3. Тренування на кардіотренажері } \\
\text { (гребний концепт, } 20 \text { хв). }\end{array}$ & 90 & $\begin{array}{l}\text { Визначити самопочуття (впевнитися у } \\
\text { відсутності больових відчуттів у } \\
\text { колінному суглобі). Здійснити } \\
\text { перевірку готовності до самостійного } \\
\text { тренування. Виконати розминку. Темп } \\
\text { виконання вправ помірний, без різких } \\
\text { рухів. Коригувати техніку бігу. } \\
\text { Слідкувати за ЧСС та диханням під } \\
\text { час роботи на кардіотренажері. } \\
\text { Наприкінці тренування виконати } \\
\text { заминку. }\end{array}$ \\
\hline 1.32 & $\begin{array}{l}\text { Заняття 32. } \\
\text { 1. Розтягнення (стречинг), дихальні } \\
\text { вправи. } \\
\text { 2. Тренування кидкової техніки } \\
\text { рукопашного бою, тренування техніки } \\
\text { одягання кайданків (обшуку) та } \\
\text { конвоювання. } \\
\text { 3. Тренування техніки бігу на } 3 \text { км. }\end{array}$ & 90 & $\begin{array}{l}\text { Визначити самопочуття (впевнитися у } \\
\text { відсутнсті больових відчуттів у } \\
\text { колінному суглобі). Здійснити } \\
\text { перевірку готовності до самостійного } \\
\text { тренування. Виконати розминку. Темп } \\
\text { виконання вправ помірний, без різких } \\
\text { рухів. Коригувати техніку бігових } \\
\text { вправ. Слідкувати за ЧСС та диханням } \\
\text { під час бігу. Наприкінці тренування } \\
\text { виконати заминку. }\end{array}$ \\
\hline 1.33 & $\begin{array}{l}\text { Заняття } 33 . \\
\text { 1. Тренування техніки човникового бігу } \\
4 \times 100 \text { м. } \\
\text { 2. Силові вправи на гімнастичних } \\
\text { снарядах. } \\
\text { 3. Тренування на кардіотренажері } \\
\text { (велотренажер, } 20 \text { хв). }\end{array}$ & 90 & 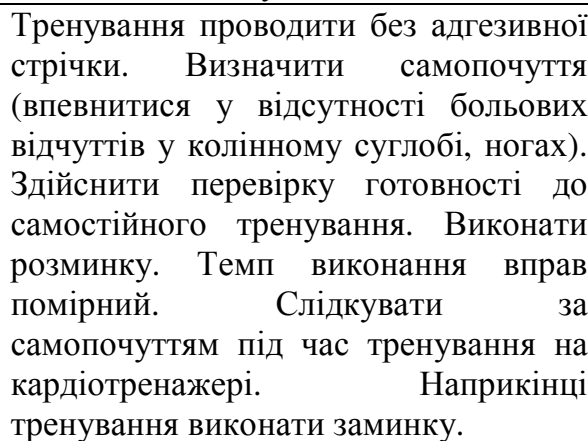 \\
\hline 1.34 & $\begin{array}{l}\text { Заняття } 34 . \\
\text { 1. Тренування техніки подолання } \\
\text { штучних та природних перешкод, } \\
\text { тренування техніки метання гранат на } \\
\text { влучність (дальність). } \\
\text { 2. Крос по пересіченій місцевості (до 5-6 } \\
\text { км). } \\
\text { 3. Розтягнення (стречинг), дихальні ката. }\end{array}$ & 90 & $\begin{array}{l}\text { Тренування проводити без адгезивної } \\
\text { стрічки. Визначити самопочутт } \\
\text { (впевнитися у відсутності больових } \\
\text { відчуттів у колінному суглобі, ногах). } \\
\text { 3дійснити перевірку готовності до } \\
\text { самостійного тренування. Виконати } \\
\text { розминку. Темп виконання вправ } \\
\text { помірний. } \text { Слідкувати } \\
\text { самопочуттям під час виконання } \\
\text { бігових вправ. Наприкінці тренування } \\
\text { виконати заминку. }\end{array}$ \\
\hline
\end{tabular}


продовження таблиці 1

\begin{tabular}{|c|c|c|c|}
\hline 1 & 2 & 3 & 4 \\
\hline 1.35 & $\begin{array}{l}\text { Заняття } 35 . \\
\text { 1. Тренування техніки підтягування на } \\
\text { перекладині. } \\
\text { 2. Навчально-тренувальні сутички за } \\
\text { спрощеними правилами рукопашного } \\
\text { бою } \\
\text { 3. Тренування техніки бігу на } 3 \text { км. }\end{array}$ & 90 & 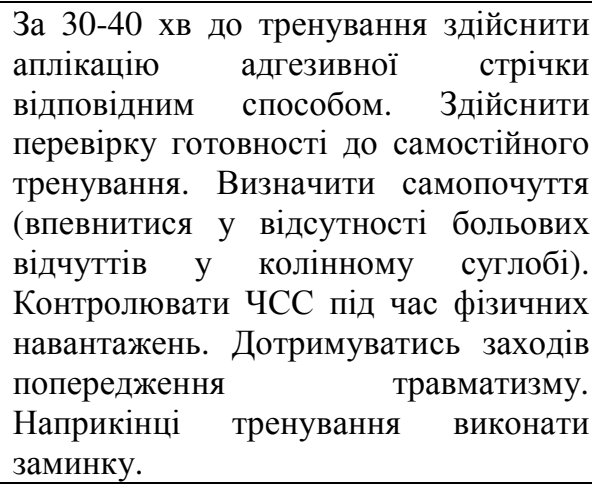 \\
\hline 1.36 & $\begin{array}{l}\text { Заняття 36. } \\
\text { 1. Тренування техніки бігу на } 100 \text { м. } \\
\text { 2. Тренування на кардіотренажері } \\
\text { (гребний концепт, } 20 \text { хв). } \\
\text { 3. Розтягнення (стречинг), дихальні ката. }\end{array}$ & 90 & $\begin{array}{l}\text { Визначити самопочуття (впевнитися у } \\
\text { відсутності больових відчуттів у } \\
\text { колінному суглобі, ногах). Здійснити } \\
\text { перевірку готовності до самостійного } \\
\text { тренування. Виконати розминку. } \\
\text { Слідкувати за ЧСС та диханням під } \\
\text { час тренування на кардіотренажері. } \\
\text { Наприкінці тренування виконати } \\
\text { заминку. }\end{array}$ \\
\hline \multicolumn{2}{|c|}{ Всього за константувальний етап } & 1080 & $-\cdots$ \\
\hline \multicolumn{2}{|c|}{ Всього за курс фізичної терапії } & 1980 & $-\cdots$ \\
\hline
\end{tabular}

Авторська розробка: В. Шемчук, Н. Вербин, О. Шемчук, С. Гайдаров, О. Хаџаюк, А. Матвєєв

У якості основних засобів фізичної терапії на етапі відновлення після лікування травм колінного суглобу нами обрані комплекси фізичних вправ, що забезпечують поетапне та збалансоване формування психофізичної готовності майбутніх офіцерів зазначених вище інституцій СБОУ до навчально-бойової та службово-бойової діяльності (виконання завдань за призначенням у різних умовах СБОД). Крім цього, використовувалася відповідна техніка кінезіологічного тейпування колінного суглобу (на рис. 2 надано варіант кінезіологічного тейпування колінного суглобу досліджуваного КГ).

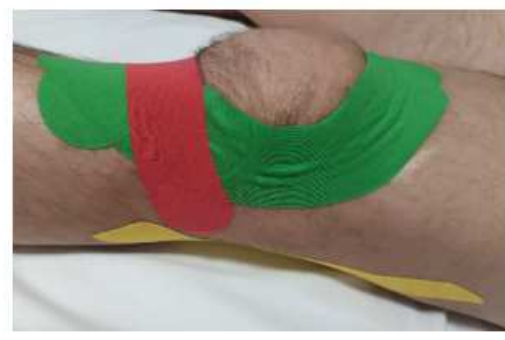

a)

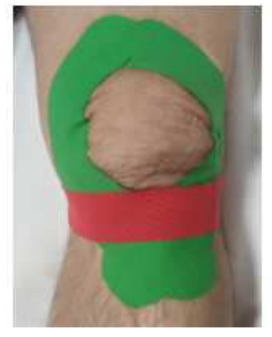

б)

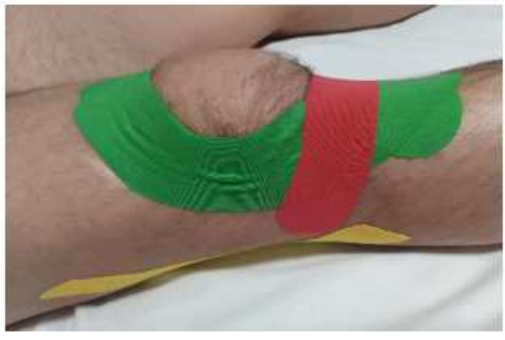

B)

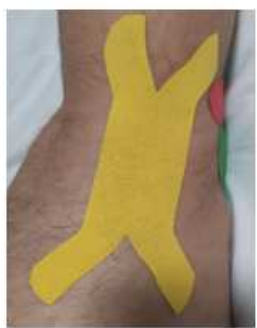

г)

Рис. 2. Варіант кінезіологічного тейпування (аплікації адгезивної стрічки) колінного суглобу (лівої ноги) досліджуваного ЕГ 3 хондромаляцією надколінника на етапі фізичної терапії

У динаміці третього етапу дослідження (серпень - листопад 2021p.), членами НДГ організовано педагогічний експеримент, який передбачав апробацію розробленої нами «методики фізичної терапії» (див. табл. 1).

В педагогічному експерименті взяли участь майбутні офіцери (курсанти 
навчально-наукового інституту фізичної культури та спортивно-оздоровчих технологій Національного університету оборони імені Івана Черняховського, Національної академії Національної гвардії України та Харківського університету внутрішніх справ, чоловіки, $\mathrm{n}=24$ ). Варто також підкреслити, що всі учасники педагогічного експерименту дали згоду на участь в дослідженнях i пройшли відповідне лікування у спеціалізованих закладах охорони здоров'я та отримали дозвіл лікарів на участь в заходах фізичної терапії із використанням методики кінезіологічного тейпування (див. табл. 1).

Надалі курсантів зазначених вище ВВНЗ, ЗВОСУН було розподілено на дві репрезентативні групи: контрольну (КГ, $\mathrm{n}=12$ чол.) та експериментальну (ЕГ, $\mathrm{n}=12$ чол.). До початку апробації розробленої нами «методики фізичної терапії» (табл. 1), досліджувані показники (фізичної підготовленості) у майбутніх офіцерів зазначених вище інституцій СБОУ, учасників КГ та ЕГ достовірно не відрізнявся $(p \geq 0,05)$.

3 метою якісного відновлення працездатності, а також досягнення необхідного рівня фізичної готовності курсантів КГ до виконання ними завдань за призначенням, в системі фізичної підготовки, форм фізичної підготовки, використовувалися діючі комплекси навчально-методичного забезпечення передбачені відповідними відомчими керівними документами (відповідної інституції СБОУ до якої належить ВВНЗ чи ЗВОСУН). У свою чергу, досліджувані майбутні офіцери ЕГ в системі фізичної підготовки (форм фізичної підготовки) на етапі фізичної терапії додатково використовували розроблену нами «методику» (див. табл. 1).

Методика фізичної терапії використовувала курсантами ЕГ упродовж третього етапу дослідження, що сприяло стійкому формуванню у них професійної компетентності (відновлення та підвищення фізичної підготовленості), які передбачені відповідними програмами навчання (відповідної інституції СБОУ до якої належить ВВНЗ чи ЗВОСУН).

Необхідно відмітити, що дослідження ефективності сформованості зазначених вище професійної компетентності (рівня фізичної підготовленості) у курсантів КГ та ЕГ здійснено із урахуванням діючої нормативно-правової бази з фізичної (спеціальної фізичної) підготовки відповідної інституції СБОУ (ЗСУ, НГУ, НПУ).

В процесі дослідно-аналітичної роботи використано метод експертного оцінювання (визначено сформованості професійної компетентності досліджуваних курсантів КГ та ЕГ за чотирьох бальною шкалою оцінювання, де «5» - максимальний бал, а «2» - мінімальний). Результати контрольного тестування фізичної підготовленості (сформованості професійної компетентності) упродовж педагогічного експерименту подано на рис. 3). 


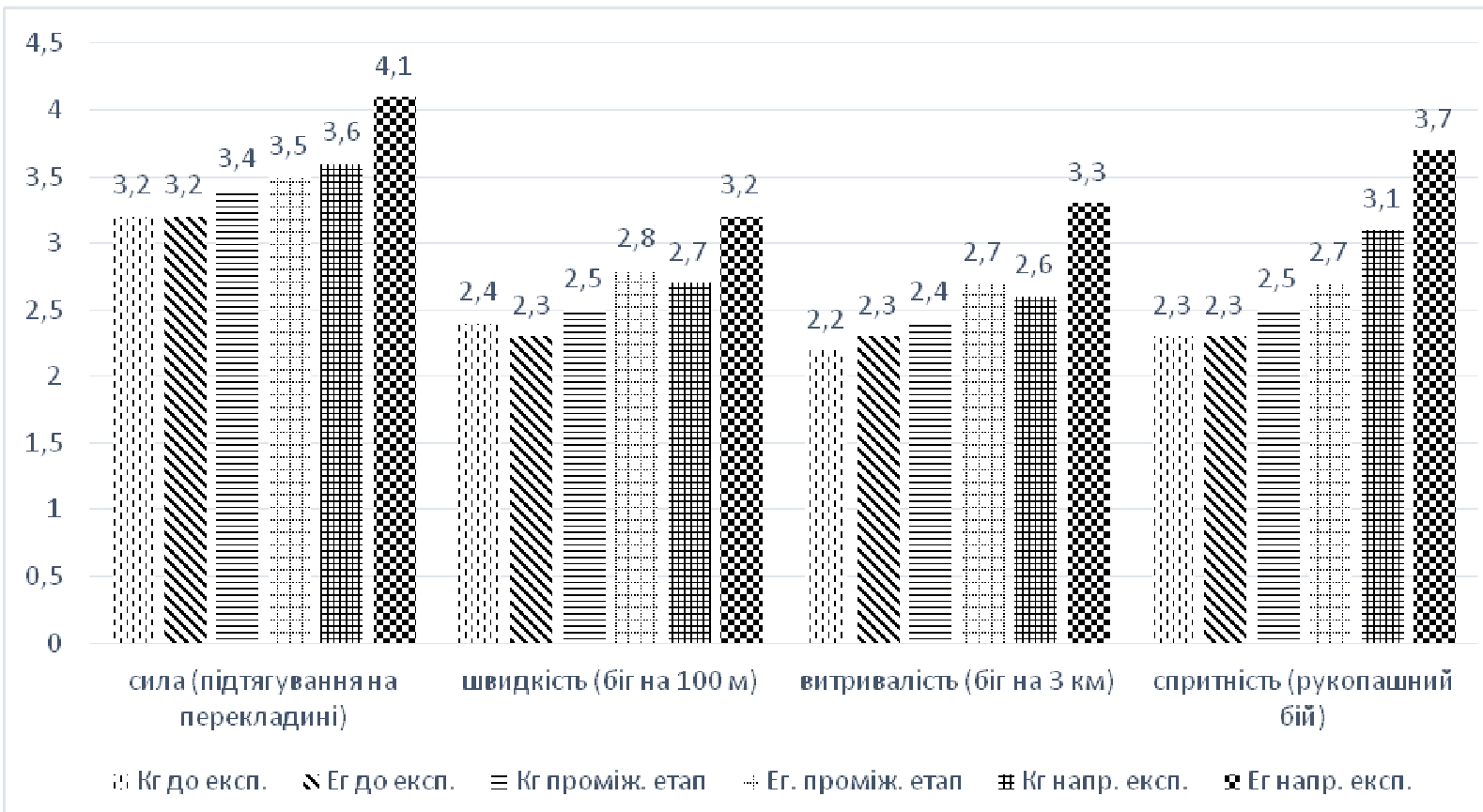

Рис. 3. Динаміка відновлення рівня фізичної підготовленості (відновлення та формування професійної компетентності) досліджуваних курсантів КГ та ЕГ упродовж педагогічного експерименту

При порівнянні показників до та після використання розробленої «методики фізичної терапії» (табл. 1) із акцентованим використанням засобів кінезіологічного тейпування встановлено, що результати, отримані наприкінці педагогічного експерименту у досліджуваних групах, зросли відносно вихідних даних, і ці відмінності переважно $\epsilon$ достовірні (ЕГ, $p \leq 0,05)$. Отже, мету дослідження досягнуто, а поставлені перед нами завдання - виконані.

Висновки та перспективи подальших досліджень. В результаті емпіричного дослідження членами науково-дослідної групи розроблено та апробовано сучасну «Методику фізичної терапії майбутніх офіцерів ЗСУ, НГУ, НПУ із використанням засобів кінезіологічного тейпування в системі їхньої фізичної підготовки».

Аналізуючи отриманні результати проведеного дослідження доцільним $\epsilon$ висновок, що запропонована нами методика фізичної терапії майбутніх офіцерів зазначених вище інституцій СБОУ із використанням засобів кінезіологічного тейпування в системі їхньої фізичної підготовки $є$ достатньо збалансованою та ефективною, про що свідчать показники виконання навчально-бойових (службово-бойових) завдань (заліків та екзаменів 3 основних навчальних дисциплін, зокрема - фізичної та спеціальної фізичної підготовки) передбачених освітніми програмами підготовки майбутніх офіцерів ЗСУ, НГУ, НПУ.

Цілеспрямована фізична терапія із використанням технік кінезіологічного тейпування $\epsilon$ запорукою успіху військовослужбовців (правоохоронців) різних категорій та вікових груп інституцій СБОУ на шляху до їхнього повного одужання при травмах чи професійних захворюваннях. Важливим також під час кінезіологічного тейпування є відстеження стану проблемної області, на яку 
здійснюється аплікація (до та після кінезіологічного тейпування). Варто пам'ятати, що кожен військовослужбовець (правоохоронець) є унікальним, i лише 3 урахуванням індивідуально-типологічних особливостей можливим $\epsilon$ досягнення позитивного результату у фізичній терапії (ерготерапії).

Результати дослідження впроваджено в освітній процес курсантів навчально-наукового інституту фізичної культури та спортивно-оздоровчих технологій Національного університету оборони імені Івана Черняховського, Національної академії Національної гвардії України та Харківського національного університету внутрішніх справ. Напрями подальших досліджень у обраному напрямі наукової розвідки передбачають удосконалення системи спеціальної фізичної підготовки майбутніх офіцерів інституцій сектору безпеки i оборони України із урахуванням їхньої майбутньої військово-облікової спеціальності.

1. Шемчук В. А. Педагогічна модель удосконалення спеціальної фізичної підготовленості майбутніх офіцерів засобами службово-прикладних єдиноборств / В. А. Шемчук, Н. Б. Вербин, О. С. Нестеров, М. М. Василенко, С. В. Малахов. - Запоріжжя : Педагогіка формування творчої особистості у вищій i загальноосвітній школі, 2020. № 71 (Т. 2). - С. 241-248.

2. Моргунов О. А. Удосконалення нормативної бази навчальної дисципліни «Спеціальна фізична підготовка» майбутніх офіцерів Національної поліції України та поліцейських різних категорій / О.А. Моргунов, О. В. Хацаюк, І. М. Ковальов, О. А. Соколов, Є. А. Лозовий. - Запоріжжя : Педагогіка формування творчої особистості у вищій і загальноосвітній школі, 2021. № 75 (Т. 2). - С. 38-45.

3. Шемчук В. Формування професійних компетентностей майбутніх офіцерів до дій в умовах радіаційної, хімічної та біологічної небезпеки / В. Шемчук, О. Хацаюк, В. Соколовський, А. Ковтуненко, О. Корнієнко, Ю. Муштатов. - Київ : Військова освіта, 2021. № 1 (43). - C. 360-381.

4. Khatsaiuk, O., Medvid, M., Maksymchuk, B., Kurok, O., Dziuba, P., Tyurina, V., Chervonyi, P., Yevdokimova, O., Levko, M., Demchenko, I., Maliar, N., Maliar, E., \& Maksymchuk, I. (2021). Preparing Future Officers for Performing Assigned Tasks through Special Physical Training. Revista Romaneasca pentru Educatie Multidimensionala, 13 (2), 457-475. https://doi.org/10.18662/rrem/13.2/431.

5. Моргунов О. А. Удосконалення прикладних навичок практичної стрільби в системі професійної освіти Національної поліції України / О. А. Моргунов, О. А. Ярещенко, О. В. Хацаюк. - Харків : Честь і закон, 2016. № 1. - С. 49-56.

6. Малолепший С. Б. Коефіцієнти ефективності застосування заходів фізичного впливу правоохоронцями МВС України / С. Б. Малолепший, М. Г. Калюжний, О. В. Хацаюк. Харків : Честь і закон, 2017. № 1. - С. 78-85.

7. Хацаюк О. В. Удосконалення військово-професійних навичок військовослужбовців Національної гвардії України в процесі спеціальної фізичної підготовки / О. В. Хацаюк, Р. І. Любчич, В. В. Оленченко. - Харків : Новий колегіум, 2019. № 1. - С. 63-68.

8. Oleniev D. G. Dynamics of the Professional Endurance Indicators in Officers of the Operational Level in a Higher Military Educational Institution During Training / D. G. Oleniev, O. V. Petrachkov, N. B. Verbyn, V. A. Shemchuk, A. M. Tiazhyna. - Canada (Lifescience Global) : Journal of Intellectual Disability-Diagnosis and Treatment, 2021. № 5 (T. 9). - P. 495-503.

9. Бриндіков Ю. Л. Теорія та практика реабілітації військовослужбовців-учасників бойових дій в системі соціальних служб : дис. ... докт. пед. наук : 13.00 .05 / Бриндіков Юрій Леонідович. - Хмельницький, 2018. - 559 с. 
10. Купріненко О. Аналіз сучасного стану та проблем ерготерапії військовослужбовців Збройних Сил України постраждалих в результаті бойових дій / О. Купріненко. - Миколаїв : Український журнал медицини, біології та спорту, 2020. № 4 (26). - С. 36-43.

11. Ковальов I. М. Фізична терапія поліцейських після лікування коронавірусної хвороби / І. М. Ковальов, К. В. Бутенко. - Харків : Підготовка поліцейських в умовах реформування системи МВС України, 2021. № 6 - С. 138-142.

12. Горпинич Г.Ф. Методика фізичної терапії викладачів спеціальної фізичної підготовки закладів вищої освіти зі специфічними умовами навчання після лікування коронавірусної хвороби /Г. Ф. Горпинич, В. А. Шемчук, Г. О. Коник, О. А. Суровов, Д.В. Аксьонов. - Запоріжжя : Педагогіка формування творчої особистості у вищій i загальноосвітніх школах, 2021. № 75. Т. 1. - С. 104-109.

13. Kenzo K. Clinical Therapeutic Applications of the Kinesio Taping Method : practical guide / K. Kenzo. - Minneapolis : OPTP, 2013. - 252 p.

14. Гончар Г. І. Критерії, рівні сформованості готовності фахівців фізичного виховання та спорту до використання методики кінезіологічного тейпування в професійній діяльності /Г. І. Гончар, Т. М. Булгакова, С. А. Лазоренко, С. В. Хоменко, Р. М. Стасюк. - Київ : Науково-педагогічні проблеми фізичної культури (фізична культура і спорт), 2021. № 9 (140). - С. 31-36.

15. Русин Л. П. Програма формування готовності тренерів з одноборств до застосування засобів фізичної терапії в системі самоосвіти : колект. моногр. / Л. П. Русин. - Вінниця : Європейська наукова платформа, 2021. - С. 1-33.

16. Кіндзер Б. М. Методика фізичної терапії самбістів із використанням засобів кінезіологічного тейпування при травмах шиї / Б. М., Кіндзер, Н. Л. Бабич, Р. Р. Сіренко, І. С. Рибчич, І. М. Ільницький, Н. В. Петренко. - Київ : Науково-педагогічні проблеми фізичної культури (фізична культура і спорт), 2021. № 11 (142). - С. 32-52.

17. Vynohradov, V., Lopatenko, H., Biletska, V., Trachuk, S., Semenenko, V., Kudria, M., Shemchuk, V., \& Napadij, A. (2020). Influence of taping on athletes' psychomotor possibilities in sprint. Journal of Human Sport and Exercise, 0, in press. doi: https://doi.org/10.14198/jhse.2022.172.19

\section{REFERENCES}

1. Shemchuk, V. A., Verbyn, N. B., Nesterov, O. S., Vasylenko, M. M., Malakhov, Ye. V. (2020). Pedahohichna model udoskonalennia spetsialnoi fizychnoi pidhotovlenosti maibutnikh ofitseriv zasobamy sluzhbovo-prykladnykh yedynoborstv [Pedagogical model of improving the special physical fitness of future officers by means of service-applied martial arts]. Pedahohika formuvannia tvorchoi osobystosti u vyshchii i zahalnoosvitnii shkoli, № 71 (T. 2), 241-248.

2. Morhunov, O. A., Khatsaiuk, O. V., Kovalov, I. M., Sokolov, O. A., Lozovyi, Ye. A (2021). Udoskonalennia normatyvnoi bazy navchalnoi dystsypliny «Spetsialna fizychna pidhotovka» maibutnikh ofitseriv Natsionalnoi politsii Ukrainy ta politseiskykh riznykh katehorii [Improving the regulatory framework of the discipline "Special Physical Training" for future officers of the National Police of Ukraine and police officers of various categories]. Pedahohika formuvannia tvorchoi osobystosti u vyshchii i zahalnoosvitnii shkoli, № 75 (T. 2), 38-45.

3. Shemchuk, V., Khatsaiuk, O., Sokolovsky, V., Kovtunenko, A., Kornienko, O. (2020). Formuvannia profesiinykh kompetentnostei maibutnikh ofitseriv do dii $\mathrm{v}$ umovakh radiatsiinoi, khimichnoi ta biolohichnoi nebezpeky [Formation of professional competencies of future officers to act in conditions of radiation, chemical and biological danger]. Viiskova osvita, Vup. 1 (43), 360-381.

4. Khatsaiuk, O., Medvid, M., Maksymchuk, B., Kurok, O., Dziuba, P., Tyurina, V., Chervonyi, P., Yevdokimova, O., Levko, M., Demchenko, I., Maliar, N., Maliar, E., \& Maksymchuk, I. (2021). Preparing Future Officers for Performing Assigned Tasks through Special Physical Training. Revista Romaneasca pentru Educatie Multidimensionala, 13 (2), 457-475. https://doi.org/10.18662/rrem/13.2/431. 
5. Morhunov, O. A., Yareshchenko, O. A., Khatsaiuk, O. V. (2016). Udoskonalennia prykladnykh navychok praktychnoi strilby $\mathrm{v}$ systemi profesiinoi osvity Natsionalnoi politsii Ukrainy [Adequate applied tools for practical shooting in the system of professional education of the National Police of Ukraine]. Honor and law, № 1, 49-56.

6. Malolepshiy, S. B., Kalyuzhny, M. G., Khatsayuk, O. V. (2017). Koefitsiienty efektyvnosti zastosuvannia zakhodiv fizychnoho vplyvu pravookhorontsiamy MVS Ukrainy [Coefficients of efficiency of application of measures of physical influence by militiamen of the Ministry of Internal Affairs of Ukraine]. Honor and law, № 1, 78-85.

7. Khatsaiuk, O. V., Liubchych, R. I., Olenchenko, V. V. (2019). Udoskonalennia viiskovoprofesiinykh navychok viiskovosluzhbovtsiv Natsionalnoi hvardii Ukrainy $\mathrm{v}$ protsesi spetsialnoi fizychnoi pidhotovky [Improving the military-professional skills of servicemen of the National Guard of Ukraine in the process of special physical training]. Novyi kolehium, Vup. 18. T. 2, 63-68.

8. Oleniev D. G. Dynamics of the Professional Endurance Indicators in Officers of the Operational Level in a Higher Military Educational Institution During Training / D. G. Oleniev, O. V. Petrachkov, N. B. Verbyn, V. A. Shemchuk, A. M. Tiazhyna. - Canada (Lifescience Global) : Journal of Intellectual Disability-Diagnosis and Treatment, 2021. № 5 (T. 9). - P. 495-503.

9. Bryndikov, Yu. L. (2018). Teoriia ta praktyka reabilitatsii viiskovosluzhbovtsivuchasnykiv boiovykh dii $\mathrm{v}$ systemi sotsialnykh sluzhb [Theory and practice of rehabilitation of servicemen-participants of hostilities in the system of social services]. (Abstract of PhD thesis), Khmelnytskyi.

10. Kuprinenko, O. (2020). Analiz suchasnoho stanu ta problem erhoterapii viiskovosluzhbovtsiv Zbroinykh Syl Ukrainy postrazhdalykh v rezultati boiovykh dii [Analysis of the current state and problems of occupational therapy of servicemen of the Armed Forces of Ukraine injured in hostilities]. Ukrainskyi zhurnal medytsyny, biolohii ta sportu, Vup. 4 (26), 36-43.

11. Kovalov, I. M., Butenko, K. V. (2021). Fizychna terapiia politseiskykh pislia likuvannia koronavirusnoi khvoroby [Physical therapy of police officers after treatment of coronavirus disease]. Pidhotovka politseiskykh v umovakh reformuvannia systemy MVS Ukrainy, № 6, 138-142.

12. Horpynych, H. F., Shemchuk, V. A., Konyk, H. O., Surovov, O. A., Aksonov, D. V. (2021). Metodyka fizychnoi terapii vykladachiv spetsialnoi fizychnoi pidhotovky zakladiv vyshchoi osvity zi spetsyfichnymy umovamy navchannia pislia likuvannia koronavirusnoi khvoroby [Methods of physical therapy for teachers of special physical training in higher education institutions with specific learning conditions after treatment of coronavirus diseasen]. Pedahohika formuvannia tvorchoi osobystosti u vyshchii i zahalnoosvitnii shkoli, № 75 (T. 1), 104-109.

13. Kenzo K. Clinical Therapeutic Applications of the Kinesio Taping Method : practical guide / K. Kenzo. - Minneapolis : OPTP, 2013. - 252 p.

14. Honchar, H. I., Bulhakova, T. M., Lazorenko, S. A., Khomenko, S. V., Stasiuk, R. M. (2021). Kryterii, rivni sformovanosti hotovnosti fakhivtsiv fizychnoho vykhovannia ta sportu do vykorystannia metodyky kineziolohichnoho teipuvannia $\mathrm{v}$ profesiinii diialnosti [Criteria, levels of formation of readiness of specialists of physical education and sports to use the technique of kinesiological taping in professional activity]. Naukovo-pedahohichni problemy fizychnoi kultury (fizychna kultura i sport), № 9 (140), 31-36.

15. Rusyn, L. P. (2021). Prohrama formuvannia hotovnosti treneriv $\mathrm{z}$ odnoborstv do zastosuvannia zasobiv fizychnoi terapii $\mathrm{v}$ systemi samoosvity [The program of formation of readiness of trainers in martial arts to application of means of physical therapy in system of selfeducation]. kolektyvna monohrafiia, 1-33.

16. Kindzer, B. M., Babych, N. L., Sirenko, R. R., Rybchych, I. Ye., Ilnytskyi, I. M., Petrenko, N. V. (2021). Metodyka fizychnoi terapii sambistiv iz vykorystanniam zasobiv kineziolohichnoho teipuvannia pry travmakh shyi [Methods of physical therapy of sambo wrestlers with the use of kinesiological taping for neck injuries]. Naukovo-pedahohichni problemy fizychnoi kultury (fizychna kultura i sport), № 11 (142), 32-52. 
17. Vynohradov, V., Lopatenko, H., Biletska, V., Trachuk, S., Semenenko, V., Kudria, M., Shemchuk, V., \& Napadij, A. (2020). Influence of taping on athletes' psychomotor possibilities in sprint. Journal of Human Sport and Exercise, 0, in press. doi: https://doi.org/10.14198/jhse.2022.172.19.

\title{
Резюме
}

Вадим Шемчук, кандидат педагогических наук, Национальный университет обороны Украины имени Ивана Черняховского

Назарий Вербин, кандидат педагогических наук, Национальный университет обороны Украины имени Ивана Черняховского

Оксана Шемчук, кандидат психологических наук, Украинская военно-медицинская академия

Андрей Матвеев, Национальный университет обороны Украины имени Ивана Черняховского

Сергей Гайдаров, Национальный университет обороны Украины имени Ивана Черняховского

\section{Методика физической терапии будущих офицеров с использованием средств кинезиологического тейпирования}

\begin{abstract}
Рассмотрена актуальная проблема внедрения в систему профессионального образования (образовательный процесс) будущих офищеров институтов сектора безопасности и обороны Украины (СБОУ) современных методик физической терапии. Учитьвая результаты анализа научно-методической, справочной и специальной литературы (мониторинга Интернет-ресурсов) в избранном направлении исследования, членами научно-исследовательской группь разработана и апробирована методика физической терапии будущих офицеров Вооруженных Сил Украинь, Национальной гвардии Украинь и Национальной поличии Украиньл с использованием средств кинезиологического тейпирования в системе их физической подготовки. Нами установлено, что результать, полученные в конще педагогического эксперимента в исследуемых группах, выросли относительно исходных данных, и эти отличия преимущественно достоверны $(Э Г, p \leq 0,05)$. Анализируя результаты эмпирического исследования, членами научно-исследовательской группь установлено, что разработанная нами методика физической терапии будущих офицеров указанных выше институций СБОУ с использованием средств кинезиологического тейпирования в системе их физической подготовки есть достаточно сбалансированной $и$ эффективной, о чем свидетельствуют показатели выполнения учебно-боевых (служебнобоевых) задач (зачетов и экзаменов по основным учебным дисииплинам, в частности физической и специальной физической подготовки) предусмотренных образовательными программами подготовки будущих офищеров Вооруженных Сил Украины, Начиональной гвардии Украинь и Национальной полищии Украинь.. Направления дальнейших исследований в избранном направлении научного поиска предусматривают усовершенствование системы специальной физической подготовки будущих офищеров институций СБОУ с учетом их будущей военно-учетной специальности.
\end{abstract}

Ключевые слова: готовность; эрготерапия; курсанты; методика; профессиональное 
образование; профессиональные компетентности; физическая підготовка; физическая терапия.

\section{SUMMARY}

Vadym Shemchuk, candidate of pedagogical sciences, The National Defence University of Ukraine named after Ivan Cherniakhovskyi Nazarii Verbyn, candidate of pedagogical sciences, The National Defence University of Ukraine named after Ivan Cherniakhovskyi

Oksana Shemchuk, candidate of psychological sciences, Ukrainian Military Medical Academy Andrii Matvieiev,

The National Defence University of Ukraine named after Ivan Cherniakhovskyi Sergey Gaydarov,

The National Defence University of Ukraine named after Ivan Cherniakhovskyi

\section{Physical Therapy Technique for Future officers using Kinesiological taping means}

Introduction. The formation of key professional competencies of future officers of security and defense institutions of Ukraine (SDIU) is carried out in the educational process, which involves mastering a number of disciplines, among which the main ones are: chosen military accounting specialty, fire training, physical training and tactical training. Given the above, the importance of physical and special physical training of future officers can be traced, because without a sufficient level of necessary military-applied skills it is impossible to ensure the implementation of tasks in different conditions of combat operations, which emphasizes the relevance of the chosen area of scientific intelligence. It should also be emphasized that during the educational process of cadets of higher military educational institutions), institutions of higher education with specific training conditions, which train personnel for SDIU institutions, it is possible to receive injuries of varying complexity, including knee injuries, which can lead to long treatment, as well as recovery. This, in turn, negatively affects the quality and effectiveness of the formation of professional competencies of future officers, which can lead to a low level of performance by them and their subordinates of combat missions in further service activities.

Purpose. The purpose of the research is to develop and test methods of physical therapy for future officers of the Armed Forces of Ukraine, the National Guard of Ukraine and the National Police of Ukraine using the means of kinesiological taping in the system of their physical training.

Methods. Research methods (at the empirical and theoretical levels): abstraction, analysis and synthesis, induction and deduction, expert evaluation, modeling, mathematical and statistical (scaling, correlation analysis, factor analysis), etc.

Results. When comparing the indicators before and after the use of the "methodology of physical therapy" developed by the NDG members (Table 1) with the accentuated use of kinesiological taping, it was found that the results obtained at the end of the pedagogical experiment in the studied groups increased relative to baseline. $(E r, P \leq 0,05)$.

Originality. The results of the research were introduced into the educational process of cadets of the Educational and Scientific Institute of Physical Culture and Sports and Health Technologies of the Ivan Chernyakhovsky National University of Defense, the National Academy of the National Guard of Ukraine and the Kharkiv National University of Internal Affairs. 
Conclusion. Analyzing the results of the study, it is appropriate to conclude that our proposed method of physical therapy of future officers of the above institutions SDIU using kinesiological taping in their physical training system is quite balanced and effective, as evidenced by the performance of training and combat (service) tasks (tests and exams in the main disciplines, in particular physical and special physical training) provided by educational training programs for future officers of the studied category. Areas of further research in the chosen area of scientific intelligence include improving the system of special physical training of future SDIU officers, taking into account their future military accounting specialty.

Key words: readiness; occupational therapy; cadets; methods; professional education; professional competencies; physical training; physical therapy. 